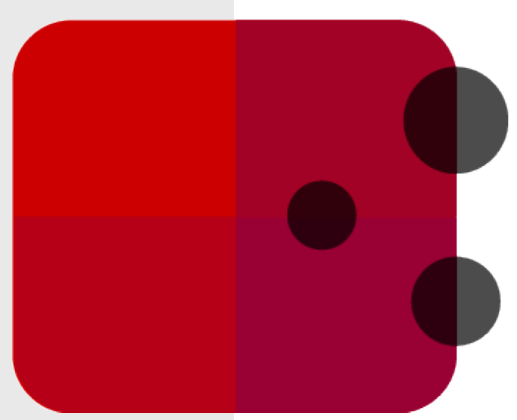

\title{
Voar é com os pássaros: inconformismo e mercado no cinema norte-americano dos anos 70
}

Marcos César de Paula Soares' 


\section{Resumo}

Este artigo discute o filme Voar é com os pássaros (1971) do diretor norte-americano Robert Altman fazendo uma reflexão sobre as confluências entre as inovações da geração de jovens diretores da chamada Renascença americana dos início dos anos 70 e o aproveitamento comercial dessas inovações "rebeldes" dentro de um quadro de crise da produção cinematográfica industrial do período.

\section{Palavras-chave}

Robert Altman, Renascença americana.

\section{Abstract}

This article discusses the film Brewster McCloud (1971) by American director Robert Altman as ways to a reflection on the convergence between the innovations brought by a generation of young directors from the so-called American Renaissance at the onset of the 1970's and the commercial use of such "rebellious" innovations within the frame of a deep crisis of the industrial production of films characteristic of the period.

\section{Keywords}

Robert Altman, American Renaissance. 
Em diversos sentidos, o filme Voar é com os pássaros (com o título original ano 2 número 3 Brewster McCloud, 1971) representa um tipo de experiência limite do cinema norte-americano, uma ousadia do diretor Robert Altman que dependeu de condições de produção que não se repetiram mais em sua carreira, mas que serviram como um modelo do qual ele sempre procurou se aproximar. As dificuldades crescentes impostas por essa empreitada tiveram a ver com o fato de que nem a revolução social, nem a revolução cinematográfica para as quais os Estados Unidos pareciam prontos no final dos anos 60 acabaram por fazer avançar limites que eram estreitos para as ambições da época. Mas aqui nos adiantamos um pouco, pois ao apontar para a discussão sobre os sonhos de liberdade e seus limites históricos, já estamos formulando sobre o tema do próprio filme.

O "estado de exceção" que caracterizou os métodos de produção da indústria norte-americana a partir do final dos anos 60 foi amplamente analisado pela crítica, que tratou de construir mitos em torno da suposta liberdade criativa característica da Renascença de Hollywood. Para mais uma vez adiantar o argumento, Voar é com os pássaros é, entre outras coisas, um filme sobre as "ilusões perdidas" dessa era que prometeu um grau de liberdade inédita para diretores jovens, cujo trabalho rebelde viria salvar a indústria da pior recessão de sua história². A geração que nascera no pós-guerra, já exaurida pela "linguagem clássica" do sistema de estúdios requentada pela televisão, exigia um cinema mais em consonância com o espírito da época. É claro que essa mesma rebeldia já passava no período pelo crivo das mentalidades mais exigentes, principalmente no que se referia às perspectivas do movimento estudantil: seria determinada por sua origem social, pequeno-burguesa, ou representava uma função social peculiar com interesses mais radicais? A dificuldade de avançar em relação a essa contradição, tanto do ponto de vista prático - para quem testemunhou e procurou intervir nas mudanças em curso no período -, quanto do ponto de vista de sua teorização posterior, fez com que, no campo da produção cinematográfica, os filmes da época e sua fortuna crítica se dividissem em duas tendências gerais:

2. De acordo com David Cook, a indústria acumulou um prejuízo total de aproximadamente 600 milhões de dólares entre 1969 e 1971. Em 1970, segundo dados do historiador, aproximadamente 40\% dos diretores de Hollywood estavam desempregados (COOK, 2000: 3). 
de um lado, as celebrações, muitas vezes nostálgicas, das glórias dos anos 60; de outro, as confissões públicas, muitas vezes abjetas, das falhas e oportunidades perdidas que caracterizaram a década. A originalidade do filme de Altman está, como procuraremos demonstrar, em evitar ambos os erros.

De qualquer modo, um dos maiores roteiristas da "era de ouro" de Hollywood, o escritor Ben Hecht, já havia resumido o sentimento geral em relação ao antigo sistema de estúdio, ao afirmar em suas memórias, que "um único enredo tem aparecido diariamente em nossos mil e quinhentos cinemas: o triunfo da virtude e a derrota da maldade" (PERLSTEIN, 2008, p. 208). É a ideia estridentemente reiterada de que "não existem problemas relacionados ao trabalho, à política, à vida doméstica, ou à sexualidade que não possam ser resolvidos por uma simples frase cristã ou um infalível bordão americano" (PERLSTEIN, 2008, p. 208).

O alvo da nova geração de cineastas será justamente o incrível espetáculo de anacronismo social que caracterizava a sociedade americana dos anos 50, formulando uma solução para o vexame que opunha a sociedade mais rica e moderna do planeta à constrangedora carolice e histeria conservadora que marcava a atmosfera ideológica do período macartista. O novo cinema dava, assim, à sociedade americana uma imagem mais em consonância tanto com o espírito de rebeldia que marcou então o surgimento dos novos sujeitos históricos (negros, mulheres e minorias sexuais) quanto com o espírito de modernização marcante nas suas práticas de dominação econômicas e militares em nível global.

O resto da história é conhecido: o modelo de jovens autores europeus como Godard, Truffaut, Fellini, Antonioni, entre outros, que havia demonstrado que a indústria e as plateias estavam prontas para certo nível de experimentação formal e ousadia temática, serviu de combustível para a imaginação de uma geração de norte-americanos que construiu seu próprio e peculiar padrão internacional de gosto, provocando uma revolução cultural no centro da indústria de entretenimento mais poderosa do planeta. Assim, a "nova onda" americana produziu dois efeitos imediatos que reaqueceram o mercado e salvaram a indústria da catástrofe: de um lado, jogou uma última pá de cal sobre o túmulo do sistema tradicional de estúdios, colocando a responsabilidade sobre as decisões criativas - assim como grande parte dos riscos de prejuízo - 
ano 2 número 3

Temáticas

Livres

nas costas de "produtores independentes", farejadores de "novas tendências" (enredos novos, vedetes novas, diretores novos). Tais produtores vendiam ideias a investidores interessados em diversificar seus ramos de atuação, antes que os grandes estúdios investissem na publicidade, na distribuição e exibição dos filmes. Em outras palavras, o sistema de produção foi terceirizado e $40 \%$ da mão de obra empregada até a década anterior despedida, criando condições cada vez mais precárias para os que ficaram.

O segundo efeito, por outro lado, foi a criação, do ponto de vista da qualidade estética, de um arejamento formal e temático de grande interesse. Parte da crítica especializada tratou de elogiar as exuberâncias visuais e os avanços temáticos que caracterizaram parte importante da produção do período. A violência gráfica e a ousadia temática do filme-manisfesto do novo cinema, Bonnie e Clyde: uma rajada de balas (1967), de Arthur Penn, veio a criar o que se caracterizou um verdadeiro "simpósio público sobre o significado do presente" (PERLSTEIN, 2008, p. 210).

No conjunto, os filmes da Renascença americana ajudaram a constituir uma visão do "período", identificando e ajudando a criar estilos, modos de pensamento e comportamento comuns que, em retrospectiva, aprendemos a identificar como aqueles dos anos 60, quando "tudo ainda aparecia possível". Em suas melhores produções, o projeto retoma aspectos da arte engajada americana dos anos 30 ao insistir em certo tipo de processo histórico, seja ao enfatizar as afinidades alegóricas entre o presente e momentos anteriores de rebeldia - o momento da grande depressão em Bonnie e Clyde -, seja ao construir analogias entre diversas áreas supostamente distintas da vida social - a confluência entre indústria cultural, contracultura, especulação imobiliária e militarismo, como em Perdidos na noite (filme de John Schlesinger,1969).

Mas o que dizer dos empréstimos formais que esses filmes realizaram a partir do cinema europeu mais avançado da época? A questão foi alvo de inúmeros trabalhos críticos, a maioria dos quais privilegia assumir os novos diretores como verdadeiros autores americanos, que foram capazes de enriquecer a linguagem dos filmes tradicionais de estúdio e criar obras nas quais expressavam uma visão altamente pessoal a despeito das pressões do aparato industrial (BISKIND, 1999; 
ELSAESSER, 2004; GILBEY, 2003; HARRIS, 2008; KOLKER, 2000; THORET, 2006; WOOD, 1986). De acordo com essa narrativa celebratória, os jovens diretores estavam em contato com a produção radical dos autores modernistas europeus e conseguiram ludibriar os produtores e outros cães de guarda, o que lhes permitiu criar filmes críticos de uma ousadia inédita na indústria.

Desde então, parte significativa da crítica americana e francesa investigou com ardor incomum as semelhanças estilísticas e iconográficas entre, por exemplo, Jules e Jim (François Truffaut, 1962) e Butch Cassidy e Sundance Kid (George Roy Hill, 1969), ou, para tomar outro exemplo muito comentado, a influência de Acossado (Jean-Luc Godard, 1959) sobre a montagem elíptica de (determinadas cenas em) Bonnie and Clyde. Os trechos cuidadosamente escolhidos para análise pela crítica são aqueles que aprendemos a reconhecer como marcos do cinema do período: o tiroteio presente no início de Meu ódio será sua herança (Sam Peckingpah, 1969) e no final de Bonnie e Clyde; a cena da perseguição de carros em Operação França (William Friedkin, 1971); a sequência do escafandro em A primeira noite de um homem (Mike Nichols, 1969); o happening de Perdidos na noite, etc.

Digamos, retomando uma formulação do crítico Frederic Jameson, que a experiência de ler diversos desses ensaios críticos assemelha-se "à escolha de bombons em uma caixa de onde os sabores indesejáveis já tinham sido sorrateiramente retirados" (JAMESON, 1992, p. 104). A aplicação localizada das conquistas da vanguarda contava aqui com o apoio de pelo menos dois desenvolvimentos então recentes, um local e outro de envergadura internacional. De um lado, o treinamento do olhar promovido por uma revolução na publicidade americana do período, que realizou uma renovação de seu repertório a partir de empréstimos das artes visuais modernistas (inclusive da Nouvelle Vague francesa) e criou um estilo "hip" que ensinava os olhares mais antenados com as novas tendências a identificar rapidamente e a apreciar arranjos visuais inusitados e refinados (FRANK, 1997).

Por outro lado, havia o desmonte do repertório das conquistas do teatro épico de Brecht por parte da terceira geração dos Cahiers du Cinéma, que sob o influxo das derrotas de 1968, passou a uma relativização das formas empregadas pelas 
ano 2 número 3

Temáticas

Livres

alas mais radicais dos cineastas europeus, de forte tendência brechtiana, e de sua redução a um receituário formalista. Essa abordagem "crítica”, que forma o currículo da quase totalidade dos novos cursos universitários de cinema abertos recentemente nos Estados Unidos, deu impulso a uma reviravolta formalista que fazia, assim, o elogio da mistura e do fragmento desmemoriado. Ela enfatizou momentos de certo hibridismo descabido, como no caso da mistura inusitada entre Godard e Kurosawa em algumas cenas do filme de Penn. Já a armação narrativa raramente foi objeto de análise, não só porque a ideia das grandes armações e de narrativas-mestras ficava fora de moda devido ao ataque pósestruturalista, mas também porque a despeito de transgressões localizadas, a armação ampla dos enredos nos filmes dessa geração conservava seu aspecto mais convencional.

Partindo dessa perspectiva, os empréstimos feitos às técnicas das vanguardas europeias podem ser entendidos como momentos de sofisticação formal empregados cosmeticamente em filmes que obedeciam, a despeito de contravenções localizadas, as exigências de construção linear de enredo. Agora que as afrontas temáticas de filmes como A primeira noite de um homem perderam parte de sua rebeldia, é com boa dose de desapontamento que verificamos que o filme é relativamente linear e convencional. Seu interesse pode estar justamente na intuição, em chave até certo ponto crítica, sobre o descompasso entre a vontade de inovar e a inutilidade do impulso diante da "caretice" inescapável do protagonista, que na cena final do filme parece estar fadado a repetir os erros da geração anterior. As mostras episódicas de virtuosismo nesses filmes não são necessariamente isentas de conteúdos importantes, enquanto que sua capacidade de subverter as regras do bom roteiro, com ênfase em indivíduos bem delineados e curva dramática, é mais discutível, como mostra com clareza o contraste com qualquer filme de Altman, com suas múltiplas camadas narrativas.

A combinação de exigências mais convencionais com o aproveitamento seletivo das conquistas de artistas exigentes não se restringe ao período. Nos anos 1930, Bertolt Brecht já havia denunciado como o procedimento industrial realiza o desmembramento do repertório em partes autônomas e estanques. Esse processo seria seguido do aproveitamento de algumas partes, desfiguradas 
e muitas vezes transformadas em seu oposto, da eliminação de outras e da transformação das crenças políticas de seus criadores em "excentricidades" (SILBERMAN, 2000). Algo da mesma ordem acontece no cinema americano dos anos 1970. O processo não se restringiu aos Estados Unidos, mas alcançou aí sua formulação industrial avançada, na qual a dificuldade de radicalização e a acomodação do radicalismo dentro de moldes convencionais, fez da Renascença de Hollywood um capítulo importante da liquidação da arte da esquerda e sua transformação num grande negócio. Para cada um dos artistas envolvidos, as contradições são complexas e muitas vezes impossíveis de evitar: é possível ser radical nas brechas do sistema? No molde industrial, as tendências radicais subvertem o sistema ou o renovam? A verdade provavelmente está na interação complexa entre as duas pressões, com artistas testando os limites da indústria cultural, enquanto o sistema industrial está sempre pronto para incorporar os novos talentos como um laboratório de formas que podem ser vendidas com a pecha rebelde de "radical".

O que testemunhamos no período é a construção de um novo "estilo internacional", ou seja, a combinação de diversas tradições nacionais sob os olhos atentos dos produtores de Hollywood. As regras de construção dessa prática foram fortalecidas pela expansão do mercado destinado ao cinema americano no período, cuja base material foi fornecida por duas medidas de Nixon na área da economia. Seguindo a enorme ampliação de crédito promovida pela política governamental, que procurava compensar pelo arrocho salarial generalizado do período, Nixon aprovou cortes de impostos para investidores locais na indústria cinematográfica (o Plano Schrieber). Já no plano internacional, foi uma medida não diretamente ligada à indústria que a salvou da falência: o fim do lastro ouro, a ascensão do "dinheiro desmemoriado" e a consequente desvalorização do dólar. As moedas estrangeiras tornavam-se mais caras e o mercado local foi inundado com investimentos internacionais, produzindo um lucro imediato de aproximadamente \$34 milhões em vendas de filmes para exibição em cinema e televisão.

Ambas as medidas fortaleceram os laços entre a indústria cinematográfica e o capital financeiro internacional. As novas qualidades exigidas para os 
ano 2 número 3

Temáticas

Livres

filmes, que tinham que atender aos gostos e investimentos de uma vastíssima plateia internacional, ajudaram a abrir o caminho para as abstrações do pósmodernismo (a dissolução das fronteiras entre a alta arte e da cultura de massas, a mistura indiscriminada de gêneros e estilos, a ideia de um novo espaço internacional sem centro, etc.).

A geração seguinte de cineastas faria ainda um encaixe mais perfeito entre a estética do híbrido e as exigências do veículo de comunicação de onde vinham partes cada vez maiores dos lucros da exportação de filmes: a televisão. Sob pressão constante dos exibidores, o começo dos anos 1960 viu um esforço conjunto de quebra da verticalização da indústria (que garantia que produção, distribuição e exibição fossem controlados pelos grandes estúdios). Tal esforço se viu coroado com a decisão da Suprema Corte pela quebra das oligarquias que dominavam o mercado cinematográfico desde os anos 1920. Como a exibição de filmes era a principal fonte de renda dos estúdios, a crise que levou à Renascença americana se acentuou gravemente. Se o retorno do público encorajado pelos novos filmes deu um primeiro impulso para a solução da crise, a aposta na distribuição mundial, e particularmente a realização da pré-venda dos filmes para exibição nas redes de televisão mundiais, acoplada à venda de produtos ligados aos filmes (brinquedos, camisetas, trilha sonora, etc.), solucionaria definitivamente a crise em meados dos anos 1970.

Assim, a mistura aleatória de gêneros intercambiáveis que veio a dominar a estética pós-moderna pode ser vista como uma acomodação dos novos filmes aos ritmos impostos pela programação televisiva. Acredito que Raymond Williams tenha sido um dos primeiros críticos a enfatizar que a televisão não deveria ser vista meramente como um acúmulo de programas isolados, mas como um fluxo (o texto pós-moderno por excelência). Nele, a mistura de diferentes gêneros e comerciais produz um tipo de subsunção da estética da interrupção, criando uma indiferenciação que reduz todos os elementos, imagens de guerra e vidros de perfume, a um patamar comum (WILLIAMS, 1974).

Os derivativos cinematográficos não tardariam a aparecer. Os filmes da nova era do blockbuster seriam caracterizados do ponto de vista formal justamente como "genre blenders": filmes como Guerra nas Estrelas é um exemplo 
paradigmático que faria escola, com sua mistura entre existencialismo pop (o embate do Bem contra o Mal), comercial de brinquedos e o aproveitamento de clichês do faroeste, da ficção científica, do romance, da comédia, num ritmo que inclui a interrupção e o fluxo.

Em meio a esse cenário e antes que a era do blockbuster se consolidasse definitivamente houve o sucesso inesperado de Mash entre críticos e público - a terceira bilheteria da indústria no ano de 1970, atrás somente de Love Story e Aeroporto, que em outra conjunção de fatores que não se repetiria. Isso deu a Altman certa credibilidade na indústria e algum dinheiro para que ele criasse sua própria produtora, a Lion's Gate, e contratasse os atores, produtores e técnicos que haviam se adaptado a seu peculiar método de trabalho no filme anterior. Em retrospectiva, Voar é com os pássaros relega até os melhores entre os filmes subsequentes de Altman a re-elaborações das questões propostas ali, quando não como regressões planejadas. A crise econômica, a ascensão vertiginosa da Nova Direita e o complicado clima ideológico do país, enquadrados por uma forte onda anti-intelectual, pioraram as condições de produção e recepção de seus filmes, muito além do que o sinistro início da década já prometia.

Diante da magnitude dos problemas históricos do período - a crise do petróleo e a inflação, a escalada da guerra no Vietnã, a desintegração da contracultura e do movimento trabalhista, a ofensiva conservadora - e da imensa renovação das teorias e das práticas cinematográficas no mundo inteiro nos anos 60, essa avaliação da importância de Voar é com os pássaros pode parecer absurda. Isso para descrever um filme repleto de piadas escatológicas, perseguições policiais, coincidências descabidas, estereótipos televisivos, atuações de qualidade duvidosa e gags infames.

De fato, muita coisa no filme parece resvalar para certo mau gosto abusado e adolescente, quando não para a "banalidade" da comédia pastelão. Entretanto, o acúmulo de infâmias que caracteriza as aventuras do protagonista adolescente está situado entre um prólogo e um final enigmáticos, que parecem destoar do resto do filme e até hoje deixam os críticos um pouco perplexos. A confusão só aumenta com as afirmações reiteradas de Altman de que, dentre seus mais de quarenta filmes, esse era seu trabalho favorito. A pista merece desenvolvimento. 
ano 2 número 3

Temáticas

Livres

Mas antes de partirmos para a análise mais detida do filme, vale a pena lembrar o leitor sobre as linhas gerais do enredo, embora grande parte do material de real interesse fique fora dessa paráfrase inicial: o filme conta a história de Brewster (Bud Cort), um jovem cujo sonho é voar como os pássaros. Ele estuda detidamente diversos livros sobre o antigo sonho humano de voar, enquanto fotografa pássaros para realizar um estudo detido da estrutura mecânica das asas.

Enquanto o sonho não se realiza, ele é obrigado a exercer diversos pequenos empregos: no início do filme, por exemplo, ele é motorista particular de um dono de asilos (Stacey Keach), lembrado da urgência de seu sonho de liberdade cada vez que é humilhado pela cretinice racista e pecuniária de diversas das pessoas que encontra. Na sua tarefa de se livrar dos empecilhos que elas representam, é auxiliado por um corvo e um “anjo”, Louise, que ronda o filme (Sally Kellerman).

Um famoso detetive de São Francisco, Frank Shaft (Michael Murphy), é chamado para resolver a série de assassinatos inexplicáveis cometidos pelos aliados de Brewster. Mais uma vez a aliança entre os três sonhadores vence a oposição do aparato repressor. Entretanto, o obstáculo maior aparece na figura de Suzanne (Shelley Duval), que seduz Brewster enquanto sugere que ele crie patentes para suas asas. Ao final do filme, perseguido pela polícia, Brewster levanta voo, mas bate no teto do ginásio de esportes onde se passa boa parte da ação do filme e morre na queda.

Já numa outra camada do filme, de caráter mais expositivo, vemos um professor (René Auberjonois) que comenta cada episódio do filme com trechos de reflexões sobre o mundo dos pássaros. É esse o primeiro personagem que encontraremos. O que chamaremos de prólogo do filme - que vai do início até o zoom in numa notícia de jornal sobre Spyro Agnew -, constrói um arco que cobre a apresentação dos créditos. Ele justapõe ambientes e grupos de personagens diferentes, unidos a cada passagem por pontes sonoras que sugerem relações entre eles.

A aparição do leão, logotipo da MGM, é um emblema apropriado para um filme sobre a domesticação e o aprisionamento. A dublagem coloca a primeira 
fala do filme, "Esqueci a linha de abertura", no lugar do rugido introduz uma abordagem paródica que se sustenta por todo o filme e sugere um distanciamento crítico típico do cinema mais avançado do período. Uma insubordinação além ou dentro dos parâmetros industriais? O início do filme já tematiza os limites do cinema industrial a contrapelo de uma virtual liberdade do cinema de autor, cujo desenvolvimento em solo americano tinha sido problematizado pela geração da Renascença de Hollywood. De qualquer modo, neste primeiro momento, o gesto rebelde corre o risco de se esfumaçar em mera desfaçatez adolescente, num bom humor inconsequente cuja força irônica se desfaz no próprio momento de sua formulação. Essa sinuca de bico que se insinua nestes primeiros segundos sugere um impasse histórico cujos traços é de interesse desenvolver.

Na sequência, a palestra do professor tem como propósito apresentar o tema a ser tratado pela próxima hora. Apesar da persistência do tom paródico, reforçado pelo esqueleto de pássaro que balança a cabeça enquanto o professor fala, é com um misto de perplexidade e interesse que o espectador ouve o professor. Sua figura ridícula não invalida a importância da questão ou seu diagnóstico do problema proposto. Os termos apresentados apontam para duas perguntas centrais: inicialmente, o estabelecimento das semelhanças entre homens e pássaros e a compreensão da vontade que o homem tem de voar, a identificação do sonho. O desejo é o de realmente alçar voo ou o de escapar da prisão da Terra e alcançar a liberdade que o voo promete?

Em seguida, o palestrante passa para uma indagação sobre as consequências nefastas da intervenção do homem nos desígnios da natureza e sobre a duvidosa solidariedade dos homens em relação aos pássaros. Nesta segunda parte, a fala é sobreposta às imagens em plano longo com a cidade de Houston ao fundo e a um movimento em panorâmica que revela o Astrodome, a "gaiola" onde se passará grande parte do filme. O relativo isolamento do Astrodome em relação ao conglomerado urbano de Houston, separado deste por uma parede verde que mal consegue se opor à poluição urbana envolvendo a cidade, tampouco consegue fazer do ginásio de esportes uma imagem de oposição ou refúgio.

As imensas extensões de concreto que cercam o espaço sugerem, pelo contrário, uma continuidade, onde a atividade física já virou parte do mundo do show 
ano 2 número 3

Temáticas

Livres

business e a natureza foi colonizada pelo planejamento urbano moderno. Assim, a abstração do discurso sobre o homem e a natureza é localizada historicamente em meio à imensa e monótona feiura de concreto e fumaça que caracteriza a maioria das cidades americanas. Assim, destoando da grandiloquência das generalizações do professor, que incluem referências à alta cultura europeia, como o poeta alemão Goethe.

Mas o prólogo não para por aí. Na sequência, a câmera enfoca o teto do Astrodome em plano longo, descendo lentamente, numa tomada sem cortes, para revelar um ensaio: uma mulher no palco entoa o hino nacional, numa ilustração às avessas da beleza do canto dos pássaros. Sua voz estridente e desafinada é acompanhada por uma banda de músicos negros, que tocam triste e mecanicamente, enquanto jovens negras estão congeladas num passo da coreografia que deverá adornar a apresentação.

Essa curta introdução é acompanhada por parte dos créditos, que dividem o espaço da tela com a figura da cantora, posicionada à esquerda do quadro, enquanto os créditos aparecem ligeiramente deslocados do centro, mais à direita. A cantora, que mais tarde saberemos tratar-se da socialite Daphne Heap (interpretada por Margareth Hamilton, que também fez a bruxa de $O$ mágico de $\mathrm{Oz}$ ), interrompe o canto, dirige-se irada na direção dos músicos e reclama de sua falta de afinação.

Numa simulação da mesma ferocidade do leão apresentada no início do filme, mas em tom rebaixado, ela lembra que é ela quem paga, quem comprou os uniformes e exige duas coisas: a afinação dos instrumentos e o uso de um painel eletrônico. Mas a quem se dirige esta última exigência? Certamente não aos músicos, que nada tem a ver com a organização geral do espetáculo.

Durante o sermão, uma das câmeras posiciona-se entre os músicos, observando a dona do espetáculo a partir do fundo. Podemos entender que, nessa convergência formal de pontos de vista, insinua-se que a bronca está direcionada tanto aos músicos como ao diretor posicionado ao lado dos músicos. Ele se coloca, portanto, como um dos trabalhadores que fazem com que as engrenagens do mundo do espetáculo girem. 
A continuação da sequência parece reforçar essa hipótese, pois não apenas os músicos retomam a música, com melhorias não muito evidentes, mas também o próprio diretor refaz o movimento. Desta vez os créditos estão centralizados, construindo mais uma vez uma paródia da "perfeição técnica" exigida pela indústria, que frequentemente se esgota na correção de detalhes de carpintaria. Trata-se de um exercício de fetiche da técnica, que se quer perfeita enquanto execução de fórmulas e padrões com sentido perdido através de seu emprego repetitivo.

Essa tensão entre a submissão às exigências da indústria cultural enquanto se realiza a exposição crítica de seus mecanismos é constitutiva de grande parte da arte mais progressista do nosso tempo e central no trabalho de Altman. Inicialmente desconectadas entre si, as três ocasiões (a apresentação do leão, do professor e da cantora) montam uma narrativa que se tece de maneira a interpelar o espectador sobre aquilo que elas têm em comum. Sugerem um grau de consciência tanto da centralidade de certos temas quanto da necessidade de transformá-los em princípio formal, a saber, numa duplicidade do ponto de vista, que transita entre a adesão às fórmulas industriais e sua exposição.

Mas o contraste que marca a continuação da sequência vem salvar o filme de certa melancolia, que vê no embate, realizado em plena era de ascensão do blockbuster, uma causa perdida e um esgotamento do gesto paródico como mera gesticulação textual: a oposição entre o motim coletivo dos músicos negros, que ao som de Lift every voice and sing (um dos hinos da luta pelos direitos civis), se recusam a repetir a sessão de tortura a que estavam sendo submetidos e os planos individuais de Brewster, que vemos pela primeira vez em sua sala do Astrodome. Ele observa os eventos pela televisão, enquanto trabalha em seus planos de libertação.

Esse contraste, sugestivo de uma ordem mais geral, dá uma pista preciosa para nossa compreensão da derrota futura de Brewster. Sua simpatia evidente pelas vítimas de uma ordem indesejada fica bastante aquém de sua capacidade de ação ou de sua compreensão histórica ampla. De qualquer modo, na primeira aparição do "anjo caído", ele observa da arquibancada, sem se intrometer, a ação dos músicos negros enquadrada por dois gigantescos símbolos da Texaco. Deixa 
ano 2 número 3

Temáticas

Livres

dúvidas sobre as possibilidades de sucesso do plano de Brewster, mas aqui já nos adiantamos. Se, entretanto, permanece invisível no chão do quarto de Brewster uma notícia de jornal sobre os processos de darwinismo social postos em prática pela administração de Nixon, o mesmo não acontece com a câmera de Altman. Num movimento de zoom in, ele busca forjar, mais uma vez, uma aliança entre o filme e o espectador. Este é incitado a liberar suas próprias projeções narrativas através da leitura de camadas secretas de significado que podem ser ignoradas pelas personagens.

De qualquer modo, a ênfase dada pelo palestrante em seus comentários sobre os processos naturais não deve nos desviar do mais essencial. O fator relevante é que os termos escolhidos pelo professor de ciências naturais descrevem práticas humanas, relações específicas entre homens: a fuga da prisão, o sonho, a conquista, o domínio e a exploração da natureza. A fluidez das fronteiras entre a descrição dos processos naturais e as práticas historicamente determinadas se confirma a cada passo.

Quando, por exemplo, o professor se refere às hierarquias sociais, às relações de dominação e às marcas de distinção social que caracterizam as relações entre os pássaros para comentar o comportamento de Mr. Wright, o dono do asilo para idosos para quem Brewster trabalha no início do filme. Ou, ainda, quando Daphne Heap, a socialite que canta o hino nacional, fica indignada com um corvo, que ela acusa de ser um nigger bird. Aqui, como de resto em todo o filme, é o vocabulário dos conflitos humanos que serve de base para a descrição dos processos da natureza. Resta a indagação sobre qual a direção que a mistura de termos tomará no desenrolar do filme. As ciências naturais que serão entendidas historicamente, ou as relações humanas que serão naturalizadas?

Já que o professor se declara um representante das ciências naturais, seria de se esperar que ele insistisse numa separação radical entre o homem e a natureza. Foi precisamente essa distinção que possibilitou a criação do campo de estudos ao qual ele se dedica, com sua descrição da natureza e seus processos em seus próprios termos, com leis e mecanismos que podiam ser estudados em si, pragmaticamente, dissociados da subjetividade humana. 
Assim, para além da abstração da natureza, que passou a ser vista isoladamente, o desenvolvimento das ciências naturais dependeu também de uma abstração do homem. Um observador atenta objetivamente, para além de qualquer determinação, para os processos igualmente objetivos que passaram a constituir a base científica do estudo. (WILLIAMS, 1994). Mas o professor, longe de aderir a uma separação rígida entre as duas esferas, a humana e a natural, passa a insistir na comparação.

O acerto das observações iniciais é evidente, como nos casos da ganância de Mr. Wright (que é comparado aos pássaros de hierarquia mais alta), da empáfia e do racismo de Daphne Heap (cujo canto é usado para a liberação de tensão) e da vaidade do detetive Frank Shaft (que lembra a generosidade com que a natureza presenteia o pavão). A partir daí, os comentários seguem-se meio indiscriminadamente, estabelecendo comparações entre os pássaros com tipos sociais bastante diversos, cujo peso na narrativa varia enormemente.

Seguem-se, em ritmo acelerado, os episódios envolvendo as aventuras de Brewster em que ele se livra, com a ajuda do corvo assassino, das figuras nefastas que atrapalham seus planos: a fuga do segurança do ginásio, o roubo de uma câmera fotográfica a ser usada para obter imagens de diversos pássaros, as ações protetoras do anjo, o conflito com um policial corrupto, etc. Assim, os comentários do professor vão criando um alto grau de fragmentação, típico de certo tipo de comédia, onde a gag (o quadro cômico) predomina sobre o enredo. Como o suspense não é sério e o herói pouco apto a encorajar a identificação do espectador, pouco interessa descobrir a identidade do assassino, mas sim observar o desfile de comportamentos ridículos das personagens, cuja exposição excede em muito as exigências estritas do desenvolvimento da narrativa central.

As inúmeras digressões e a dispersão narrativa que resulta delas, acopladas ao flagrante desrespeito às regras do realismo e da verossimilhança podem sugerir um modo onírico de organização narrativa. Elas beiram o absurdo, quando, por exemplo, Louise transforma rolos de filme roubados por Brewster em vidros de xampu para ludibriar o segurança da loja. No entanto, a linguagem do filme se aproxima mais da estética homogeneizante da televisão, cujos desfiles de gêneros, ritmos, heróis, vilões, personagens secundárias e produtos diversos vão 
ano 2 número 3

Temáticas

Livres

produzindo uma indiferenciação, uma repetição cujo fluxo indistinto desconhece ênfases ou marcações especiais. Digamos que a equivalência entre rolos de filme e xampu vale para uma organização social que estabelece a equivalência generalizada dos frutos do trabalho humano alienado. Esse processo atinge seu clímax na utilização desses produtos num meio de comunicação onde imagens de guerra e vidros de perfume podem ser consumidos de maneira indiferenciada.

Como insistimos anteriormente a respeito de certa tendência da Renascença americana, a prática do empréstimo seletivo que o molde industrial efetua ao repertório artístico transforma tais embelezamentos em unidades homogêneas mais ou menos intercambiáveis. Há supressão de sua dimensão qualitativa e reutilização em contextos padronizados de acordo com a fórmula industrial, cuja banalidade se serve dos empréstimos para promover pseudo-valorizações, numa sequência de momentos falsamente individualizados.

Em Voar é com os pássaros Altman, ao invés de evitar o procedimento, o leva às últimas consequências. Se, no prólogo, a tarefa de estabelecer equivalências entre elementos díspares apontava para o papel progressista que o espectador era chamado a exercer, no uso da linguagem da televisão, o estabelecimento de equivalências encontra sua formulação mais rebaixada. Mas para voltar às metáforas com a natureza utilizadas no filme, nada há nada natural - ou seja, inevitável - na linguagem da televisão.

Novamente foi Raymond Williams que avisou seus leitores sobre o perigo do que ele chamou de determinismo tecnológico, ou de Darwinismo aplicado ao estudo dos meios de comunicação modernos, com sua crença no emprego social naturalmente determinado pela tecnologia em si. A transmissão televisiva parece se adequar naturalmente à recepção individualizada, com seus aparelhos cada vez mais leves e menores. Lembremo-nos de Brewster assistindo à revolta dos músicos negros pela televisão. Mesmo ela pode ser vista como uma resposta a uma lógica social de fragmentação crescente na sociedade contemporânea.

De resto, as imagens do filme, ao invés de reforçarem as declarações do professor sobre a natureza, mostram um mundo onde já não restam áreas naturais intocadas. Houston é composta por enormes extensões de concreto que formam 
um cenário pouco condizente com os arroubos poéticos, científicos ou filosóficos do professor. As únicas áreas de beleza natural que o filme mostra são: os jardins obsessivamente cuidados de Daphne Heap - que com suas tesouras constrói uma paródia do mundo rural e inocente do Mágico de $\mathrm{Oz}$-, as pequenas praças e gramados que quebram a monotonia insuportável das estradas, as áreas verdes intensamente mercantilizadas do setor de serviços da cidade - o zoológico e o cemitério - e, finalmente, os parques temáticos. Neles, a natureza é transformada em motivo para um passeio de barco pela história disneyficada das selvas do terceiro mundo, naquele momento pesadamente bombardeadas pelas tropas americanas no Vietnã.

Na verdade, Voar é com os pássaros mostra um mundo que nem sequer parece ter passado pelos anos 60. O surgimento das novas identidades coletivas e dos novos sujeitos da história que caracterizou a referida década passou despercebido por Houston, a não ser na adoção de certas personagens com traços do estilo e do comportamento rebelde associados ao período. Esse é o caso da festinha hippie de Haskell Weaks, um dos políticos corruptos do enredo.

Já em outra cena rápida vemos um hippie menos abastado sendo preso. É preciso ter capital para embarcar na contemplação interior que a filosofia hippie prega. Outros aspectos mais progressistas do período, associados ao movimento de luta pelos direitos civis e ao feminismo, aparecem invertidos. A divisão social é brutal, com negros ocupando posições claramente inferiores, enquanto o avanço da posição das mulheres é tristemente ignorado pela viúva do policial corrupto. Ele passa rapidamente de um casamento infeliz e violento para outro que promete desenlace semelhante.

O sucesso da estratégia de neutralização dos impulsos rebeldes da geração encontra sua tradução melhor acabada nas figuras de Suzanne e de seu namorado. Ele é o primeiro a abraçar as novas possibilidades políticas do período ao cortar o cabelo, mudar de roupas, adotar um comportamento mais servil e encontrar emprego como assistente de um político ocupado com o tráfico de influências.

Por outro lado, Suzanne persiste em comportamentos mais próximos da rebeldia juvenil do período nas roupas e maquiagem exageradas, no desrespeito 
ano 2 número 3

Temáticas

Livres

à propriedade privada -ela rouba um carro - e à religião - ela tem uma estátua da Virgem Maria, que está "na moda" -, no afrontamento da ordem e da lei, na promiscuidade sexual. Mas ela canaliza sua criatividade para a função de guia do Astrodome, emprego de quinta categoria dentro da indústria do show business. Suas ambições são melhor reveladas, é claro, quando ela expressa o desejo de criar patentes para as asas de McCloud.

A pacificação forçada e o apagamento sistemático das conquistas dos anos 60 fizeram parte de um amplo leque de procedimentos de retomada da ordem proposto pela Nova Direita, cujo braço político é explicitamente citado no filme. A notícia de jornal no chão do esconderijo de McCloud faz referência à defesa feita pelo vide-presidente Spyro Agnew em relação a práticas de Darwinismo social. Os efeitos destas, como o desmonte do Estado de Bem Social que, na versão conservadora da época, auxiliava a sobrevivência de preguiçosos e baderneiros, assistimos até hoje.

De resto, o dinheiro público tinha destinos “mais importantes", principalmente no Texas cenário do filme. A importância nacional deste estado cresceu enormemente com a crise do petróleo e suas oligarquias, pesadamente subsidiadas pelas verbas públicas, passaram a controlar todas as decisões políticas importantes do país. Isso se dá também na vida cultural de Houston. Segundo as informações da guia Suzanne, o Astrodome estava localizado "no único lugar do Texas onde se pode cavar tão fundo sem atingir petróleo" (DAVIS, 1999).

Mas o filme mostra outro tipo mais "simpático" de seleção: os assassinatos cometidos por McCloud e seus assistentes. É com certo prazer que assistimos à eliminação de tipos nefastos, como Mr. Wright, Daphne Heap, o policial corrupto e o dono do carro roubado por Suzanne. Apesar da evidente imbecilidade dessas pessoas, o fato é que, na verdade, eles representam tipos mais ou menos inofensivos, pelo menos da perspectiva dos planos de McCloud.

Justificam o prazer que temos em ver cada um deles ser sumariamente executado: a lista interminável de adjetivos pouco lisonjeiros que Mr. Wright dirige a McCloud, o canto insuportavelmente desafinado de Daphne Heap - de resto, já vencida pela ação conjunta dos músicos negros -, as ameaças do policial 
corrupto - conhecido entre seus colegas como incompetente e desonesto - e o perigo do dono do carro, cuja camiseta, com estampa de porquinho, deixa dúvidas sobre sua agressividade. Mas eles garantem pouca adesão à figura de McCloud, cuja simpatia depende em última instância de nossa avaliação sobre seus propósitos. Retomando a pergunta do prólogo, afinal qual é o sonho de McCloud, mola propulsora da maioria das ações do enredo?

Na comparação entre natureza e sociedade proposta pelo professor, é a figura de McCloud que aparece como central. Nela se concentra o desejo de imitação proposital e bem estudada dos pássaros. Como o cenário americano é pouco propício para o desenvolvimento minimamente convincente de narrativas mitológicas, o projeto tem um quê de amalucado, mas pode ser comovente devido à pureza do ideal quase ascética - que exige uma negação da corporalidade e da sexualidade. Isso num mundo onde há tão poucos, como bem lembra o professor no prólogo.

O fervor com que ele se entrega à concretização do sonho subsume e regula todas as outras atividades da vida. Até o trabalho como motorista funciona apenas como estratégia para se apoderar de um livro antigo, que traz a fórmula fundamental para o sucesso da empreitada. De fato, parte importante do apelo das ações de McCloud é que elas remetem não apenas à ideia de trabalho humano em geral, mas à ideia de um tipo de trabalho que exige prazer, criatividade, imaginação e empenho, isto é, um trabalho não alienado.

Basta pensar numa das primeiras imagens relacionadas a trabalho no filme para entender a diferença: músicos negros submetidos à ladainha insuportável da socialite. Para entender as ressonâncias utópicas das atividades desenvolvidas por McCloud durante o filme basta também pensar em outro fenômeno do período, a proliferação de teorias de gerenciamento científico na indústria e nos serviços, em outro exemplo da combinação entre ciência e sociedade (BRAVERMAN, 1974).

Mas voar para onde? Para McCloud, a abstração do desejo, que está fadado ao fracasso desde o início, acaba por corroer as bases do trabalho não alienado. Este, para existir e fazer sentido, precisa de sua realização social 
ano 2 número 3

Temáticas

Livres

- coletiva -, ou precisa ver-se degradado em privilégio. Nesse sentido, o sonho de voar de McCloud é apenas outra face do sonho da celebridade, cujo lado ridículo se vê na figura de Frank Shaft. Seu limite ideológico e prático é a solução - no caso, a fuga - individual que supera a homogeneização intolerável e a banalidade generalizada da vida, mas mantém intactas as condições das quais se desejou escapar.

Mais do que o darwinismo social explícito da era Nixon, naturalizando e ratificando o egoísmo econômico que forma a base real do capitalismo, um dos alvos principais do filme é a face obscura de outro tipo de darwinismo social. Aquele que já não busca universalizar uma natureza bela, sábia e equilibrada, mas uma natureza da desordem, do instinto selvagem e irracional. É dessa visão generalizada de cada um por si que surge uma aceitação e uma ratificação da falta de esperança, do desespero, do fim da qualquer ação social possível, numa universalização da desintegração e do caos. Ainda pior, da ideia de que não há alternativas e de que todo sonho ou tentativa de solução está fadado ao fracasso. Essa noção é endossada no final do filme pela narração do professor, que observa a "impossibilidade de adquirir a capacidade que os pássaros levaram milhares de anos para desenvolver".

Essa falta de compromisso com ideais de liberação reais, construídos em uma base coletiva sólida que lhes possa assegurar a realização efetiva, dá ao sonho delirante de McCloud um caráter de megalomania. Seu teto está na disponibilidade de adiar a realização de seus verdadeiros fins, tornados impossíveis pela abstração que está em sua origem, para conquistar objetivos mais factíveis. Mas estes se revelam contrários ao desejo inicial, daí a mudança de alianças de McCloud, que troca a proteção de Louise pelo relacionamento com a alpinista social Suzanne, o que garante sua derrota final. Como retrato e diagnóstico da Renascença americana e suas novas narrativas de liberação, não há na produção cultural americana do início dos anos 1970 nenhum retrato mais devastador.

Mas como observei no início deste artigo, o foco narrativo não se restringe à visão do professor, mas a toma como base para fazer sua crítica. A duplicidade de foco apontada revela outra instância organizadora, que parte das generalizações do professor para ir além delas. Nesse sentido, as imagens do filme sempre 
mostram um excesso em relação aos motes que lhes servem de base. De fato, como já apontado, o acerto dos comentários do professor são evidentes e mesmo seu veredito final é acertado. Com sonhos como esses, imaginados dentro de um teto que lhes reduz o horizonte, não há possibilidade de liberação efetiva.

Se, por um lado, os comentários generalizam e tornam os fenômenos observados abstratos e homogêneos, por outro, é inegável que eles revelam certa verdade do mundo que comentam. Trata-se, no diagnóstico de Altman, de um mundo nivelado por baixo, que vendeu seus sonhos a preço de banana e há grande poder de revelação no mau gosto, que impera naturalizado na vida.

Mas a mera exposição da catástrofe, sem dúvida utilíssima, pode redundar na mesma generalização e ratificação da falta de saída senão recorrer a práticas reais de reversão dos problemas apontados. Nessa perspectiva, o filme parte do mau gosto, expresso pela linguagem da televisão, e se transforma num verdadeiro exercício de cognição e decodificação.

Para a demonstração do modo de composição do filme, retomemos a análise detalhada de cenas a partir de onde paramos: o final do prólogo do filme. O primeiro capítulo da lição do professor remete ao milionário Mr. Wright e ao tema formulado pelo comentário do professor a respeito das hierarquias sociais que caracterizam a vida coletiva dos pássaros. A sequência de imagens mostrará McCloud trabalhando como motorista, levando o milionário aos asilos de velhos, onde ele efetua suas visitas e cobranças mensais.

O roteiro das visitas é acompanhado por elementos de ligação entre as cenas, notadamente a voz vinda do rádio, que noticia os assassinatos misteriosos ocorrendo em Houston e a chegada do detetive de São Francisco. Esse narrador, que se sobrepõe aos comentários do professor, dá conta das informações típicas de um filme de detetive. De modo irônico ela expõe praticamente a totalidade das informações centrais que compõe o roteiro original do filme.

O centro dessa camada de significado é o enredo em sua formulação industrial, que o espectador não é encorajado a levar a sério A ela está justaposta uma série de imagens - as visitas aos asilos - que pouco ou nada contribuem para o suspense que uma história de detetives tradicional exigiria. $\mathrm{O}$ interesse aqui se 
ano 2 número 3

Temáticas

Livres

coloca ao lado da exposição das humilhações constantes sofridas por McCloud e da natureza repetitiva e mecânica de seu trabalho. Ela é reforçada pela edição, que enfatiza a reiteração das humilhações através da justaposição de cenas semelhantes ligadas por cortes rápidos.

Para retomar um assunto já tratado, é o retrato de seu trabalho alienado que ajudará a dar peso aos planos de fuga de uma vida insuportável. Além disso, a sequência efetua a exposição de outro fenômeno social em estágio adiantado, a saber, o processo de darwinismo social introduzido pela notícia de jornal e ampliado aqui. A "sobrevivência dos menos capazes” só interessa se puder gerar renda para beneficiários das práticas governamentais de "não intervenção", como os donos de asilos. Embora às vezes eles tivessem que enfrentar inconveniências, como a inadimplência de clientes que morrem antes de pagar a semana inteira. Finalmente, a punição efetuada por McCloud é acompanhada de outro comentário. Enquanto Mr. Wright desce a rua em cadeira de rodas, ouvimos a música que ironiza uma obsessão pelo dinheiro.

Essa sobreposição de vozes narrativas e de comentários se multiplica na sequência imediatamente posterior, aquela que mostra a chegada do detetive Shaft. Ela começa com outro mote feito pelo professor, agora sobre a vaidade dos pavões, e continua nas notícias de rádio que louvam as habilidades profissionais da polícia da Califórnia. Estas são de fonte não-diegética e, portanto, não realista, ocupando a função de voz narrativa. Enquanto isso, a câmera, em flagrante desrespeito às regras de constituição do enredo, contradiz os comentários do rádio ao enfatizar as combinações de cores que ocupam grande parte da atenção do detetive (sapatos, cintos, suéteres, malas).

Enquanto isso, o cenário funciona como comentário, enfatizando a vaidade do detetive: um pavão que enfeita a cama do hotel, as molduras superelaboradas do espelho diante do qual ele testa as diversas combinações de cores de suas roupas. Tudo parece ligá-lo a certa sensibilidade narcisista e kitsch.

Logo em seguida, o policial-assistente Johnson (John Schuck) serve de narrador. Ele conta os detalhes do assassinato de Daphne Heap, que já havia sido mencionado pelo noticiário da rádio e que vemos agora, em flashback, pela 
primeira vez. Por outro lado, não é apenas a voz do policial que liga o quarto do hotel à cena do assassinato, mas também a música de fundo. Trata-se do tema Over the rainbow do filme $O$ mágico de $O z$, que lembra o público da presença da atriz Margaret Hamilton. Enquanto isso, o movimento de zoom nos sapatos da personagem morta produz uma relação entre ela e o detetive, cuja preocupação com a cor dos sapatos já havíamos testemunhado.

Produz-se, assim, uma sobreposição de narrações e comentários que produzem relações que superam em muito as exigências de construção do enredo e exigem nossa atenção. Essa desnormatização desabusada da construção do enredo persistirá durante todo o filme e constitui, de fato, um princípio formal.

Há uma rede complexa de vozes narrativas - os motes do professor, as notícias do rádio, a edição de cenas, os movimentos de câmera, a narração de estórias e a utilização da música -, que não confluem para a construção dramática do enredo. Soma-se a elas um princípio formal no qual Altman vai insistir: um princípio de edição que contrapõe a coisa mostrada aos observadores internos das cenas. Na sequência da visita aos asilos, as atitudes pouco simpáticas de Mr. Wright são justapostas a enquadramentos de suas vítimas, neste caso, os velhinhos, mas também o próprio Altman, que aparece refletido no espelho do carro do milionário.

Ele está entre as vítimas dos abusos, assim como os observadores da "vida real" que assistem à filmagem da descida da cadeira de rodas através dos acidentes de trânsito e que a câmera deliberadamente não procura esconder. Esses pontos de vista internos se multiplicam por todo o filme - os turistas no Astrodome e no parque temático, os repórteres e curiosos no zoológico, os convidados no enterro do policial corrupto e, é claro, os espectadores do Astrodome. Eles constituem uma multidão de observadores impotentes diante do desenrolar dos eventos. Mas o processo que vitimiza os observadores também aniquila a vida do que é observado.

Para Frank Shaft, que se comporta como uma estrela, a presença de observadores se universaliza, constituindo a razão de sua existência. Ele só existe para ser visto. Para retomar uma formulação de Guy Debord, a vedete, 
ano 2 número 3

Temáticas

Livres

“aparecendo no espetáculo como modelo de identificação, [...] renunciou a toda qualidade autônoma para identificar-se com a lei geral de obediência ao desenrolar das coisas" (DEBORD, 1972, p. 76). O trabalho alienado, visto na sua versão mais gloriosa, aquela do ponto de vista da vedete, revela aqui sua face mais desumanizadora.

Assim, podemos ler o filme como uma análise de um ponto de vista que procura se impor como único na cena cultural: o universo do show business. Já que estamos tratando de um filme sobre voos, é bom lembrar que uma das primeiras formulações teóricas sobre o cinema é o elogio de seu "olhar sem corpo". Mas dentro da própria teoria cinematográfica, desde o início do século é possível mapear uma mudança gradual do elogio às infinitas possibilidades do novo meio. Trata-se de sua capacidade de adotar vários pontos de vista e de contar várias histórias para a "naturalização" de um único tipo de filme, que passou a servir de modelo para a produção industrial: o filme dramático. Nele, o olhar sem corpo seria aquele capaz de adotar apenas os melhores pontos de vista para contar uma história, sem desvios ou informações desnecessárias. É contra esse limite do olhar, desse teto que suprime o voo, que o cinema de Altman vai se rebelar.

Mas Altman sugere que essa rebelião não pode se dar através do desejo do refinamento do gosto do público. Como gostava de lembrar Brecht, o "gosto público do público não será mudado por melhores filmes, mas apenas através da melhoria de sua qualidade de vida" (SILBERMAN, 2000, p. 168). O papel produtivo do mau gosto, portanto, não está em seu mascaramento, pois é nele que está a verdade da vida. O horror da vida social está sempre à espreita por trás da máscara e só pode ser disfarçado com o reforço das camadas de ilusão. No filme, o uso da câmera lenta e da música para mostrar diversos voos de carros em plena perseguição não esconde a banalidade em curso na cena. Mas é no movimento de apontar para a própria máscara que está a força do filme, que carrega nas tintas do mau gosto sem disfarces para apontar para o processo de sua exposição e sua des-naturalização através da inteligência.

Nos anos 1970, a produção industrial em Hollywood concentraria diversas narrativas de naturalização, sendo a principal delas o estudo científico do gosto 
popular através da transformação dos departamentos de marketing no centro nervoso da indústria. Pela primeira vez na história do cinema americano os custos da promoção dos filmes passaram a exceder os custos de produção. Como uma das estratégias melhor sucedidas de superação da crise econômica tinha sido a pré-venda do direito de exibição dos filmes nas redes de televisão, um estudo estatístico do gosto popular se tornou uma necessidade primordial. Mas como todos os que acompanham as lutas das redes de televisão por audiência até hoje sabem, a indústria não pode prever tudo e frequentemente erra. Sua vantagem, mais do que deter o conhecimento sobre aquilo que o povo quer ver, está simplesmente no fato de que ela possui capital para sustentar os riscos e cobrir as perdas.

O final de Voar é com os pássaros mostra a vitória do show business. Mas mostra também o preço em vidas humanas, o que lhe retira grande parte da glória. Se a sequência final é uma citação referente a 81/2 de Fellini, vale à pena marcar as diferenças. O silencioso circo de Fellini mostrava um diretor que queria submeter trabalhadores às suas memórias pessoais, cujas violências o filme vai mapeando. No filme de Altman, a violência do espetáculo conta com a anuência de uma numerosa e festiva plateia de espectadores, que aplaudem a queda de Brewster e transformam o espetáculo, para parafrasear a formulação extraordinária de Guy Debord, na "linguagem de unificação da consciência e do olhar" (DEBORD, 1972, p. 12). Mas eles não são todos e o cinema de Altman procura encorajar uma outra relação com o espectador. 


\section{Referências}

ano 2 número 3

Temáticas

Livres

BISKIND, P. Easy riders, raging bulls. New York: Touchstone, 2003.

BRAVERMAN, Harry. "Labor and monopoly capital”. New York: Monthly Review, 1974.

COOK, D. Lost illusions. New York: Scribner, 2000.

DAVIS, M. Prisoners of the American dream. New York \& London: Verso, 1999.

DEBORD, G. La société du spectacle. Paris: Gallimard, 1972.

FRANK, T. The Conquest of the Cool. Chicago \& London: The University of Chicago Press, 1997.

GILBEY, R. It don't worry me: Nashville, jaws, Star Wars and beyond. London: Faber \& Faber, 2003.

HARRIS, M. Pictures at a revolution. five movies and the birth of the new Hollywood. New York: The Penguin Press, 2008.

JAMESON, F. Signatures of the visible. New York \& London: Routledge, 1992.

KOLKER, R. A cinema of loneliness. New York: Oxford University Press, 2000.

PERLSTEIN, R. Nixonland. New York: Scribner, 2008.

SILBERMAN, M. (ed.). Bertolt Brecht on film \& radio. London: Methuen, 2000.

SZONDI, Peter. Theory of the modern Drama. Chicago: University of Minnesota, 1987.

THORET, J.-B. Le cinema américan des annés 70. Paris: Edition Cahiers di Cinéma, 2009.

WILLIAMS, R. Television and cultural form. London: Wesleyan University Press, 1992. . The politics of modernism. London \& New York: Verso, 1994.

WOOD, R. Hollywood from Vietnam to Reagan. New York: Columbia University Press, 1986. 